\title{
Trends in the Retirement System of the United States
}

\author{
Lucy apRoberts \\ Institutions and Historical Dynamics of Economics (IDHE), Université de Paris X, Maison Max Weber, \\ Bâtiment K, 200 avenue de la République, 92001 Nanterre Cedex 01, France. \\ E-mail: laproberts@gmail.com
}

Since the 1950s, poverty among older Americans has become quite rare compared to the rest of the population. The retirement system has two main components: the social insurance system called Social Security provides the population age 65 or over with 39 per cent of their total income; occupational pension plans provide another 19 per cent of the older population's total income. Since 2000, Social Security pension levels have dropped for new retirees if they begin to get a pension before age 66 . Coverage by occupational pension plans is on the wane. In future, these developments could lead to an income shortfall for those older Americans who do not save more or postpone retirement. The financial crisis has undermined confidence in savings as a reliable source of income. In recent years, there has been a slight increase in the labour force participation of the older population, including those over 65. Nonetheless, many Americans retire at 62, as soon as they can begin to draw a Social Security pension. If current policy concerning Social Security does not change, poverty could become more common than it is today among older Americans. The Geneva Papers (2009) 34, 618-630. doi:10.1057/gpp.2009.28

Keywords: United States; retirement system; pensions; retiree incomes

\section{Introduction}

The economy of the United States provides most older Americans with a relatively good level of income compared to the younger population. Between 1959 and 2002, the proportion of Americans age 65 and over with incomes below the "poverty line", the absolute measure of poverty commonly used in the United States, declined from 35 per cent to just over 10 per cent, while the proportion for the population as a whole dropped from 22 per cent to 13 per cent. ${ }^{1}$ This would indicate that older Americans were not as well off as the rest of the population in the 1950s and that, over time, poverty has become relatively rare among the older population.

The retirement system of the United States has two main components: a single federal programme, which Americans refer to as "Social Security", and a myriad of occupational pension plans for employees. Social Security covers all private sector workers, both employees and the self-employed, and the majority of public sector employees, who work for the federal, State and local governments. Occupational pension plans cover almost all full-time employees in the public sector, but coverage is on the wane in the private sector. At their apogee, occupational pension plans

\footnotetext{
${ }^{1}$ Toder (2005)
} 
covered some 40 per cent of private sector employees; today the proportion is around 20 per cent.

Many retirees derive part of their incomes from savings, some of which come from occupational savings plans. Many older people who are receiving a pension from Social Security or from an occupational plan also have income from work.

In future, pensions might dwindle, due to cut backs in Social Security pensions and the decline of occupational pensions. If Americans work more at older ages or if they save more, they could maintain their retirement incomes. In recent years, older people have been working more than previously, but the financial crisis tends to discourage attempts to save more for retirement.

\section{An overview of the sources of retirement income}

Yearly data on the incomes of the older population is available from the Current Population Survey conducted by the national Bureau of the Census on behalf of the Labour Department's Bureau of Labour Statistics. These data trace the composition of older people's incomes by source. Age groups are classified by the age of individuals living alone and by the age of the oldest member for cohabiting married couples.

The category of households of people age 65 and over thus comprises many people who are not retired, both people age 65 and older who have earnings from work and spouses under 65 years of age who earn money. Nonetheless, age 65 is a useful cut-off point for studying the composition of retirement incomes. Table 1 shows the breakdown of incomes of the older population as a whole by source in 2007.

The single largest source of retirement income for Americans is Social Security. The programme's official name is Old Age, Survivors' and Disability Insurance or OASDI. In addition to retirement pensions, this programme pays out disability pensions to people under the age 65 and pensions to surviving family members in the event of a contributor's death. In 2007, Social Security provided 38.6 per cent of the total income of the population age 65 and over.

The second largest source of income of the older population is earnings, which accounted for 25.3 per cent of their total income in 2007. However, a part of the earnings received by the population age 65 and over comes from working spouses who are below age 65 .

The category "occupational pensions and annuities" includes occupational pensions paid out by plans for private and public sector employees, as well as annuities

Table 1 Income of the population age 65 and $o v e r^{\text {a }}$ by source, 2007

\begin{tabular}{lc}
\hline Income source & \% of total income \\
\hline Social Security & 38.6 \\
Earnings & 25.3 \\
Occupational pensions and annuities & 18.7 \\
Income from assets & 15.6 \\
Other income & 1.8 \\
\hline
\end{tabular}

${ }^{a}$ Individuals living alone age 65 or over and couples with at least one member age 65 or over. Source: EBRI (2008, Table 7.5). 
Table 2 Breakdown of income from "occupational pensions and annuities", 2007

Income source

Private sector occupational pension plans

Public sector occupational pension plans

Retirement savings plans (IRAs, Keogh plans, 401(k) plans, etc.)

Annuities purchased with retirement savings

Other retirement income

Total

As a percentage of total income of the population age 65 and over.

Source: EBRI (2008, Table 7.2).

purchased with sums saved through optional tax-favoured individual retirement savings accounts. The latter comprise individual arrangements (Individual Retirement Accounts or IRAs, Keogh plans for the self-employed) as well as occupational retirement savings accounts, referred to as "401(k) plans" when they concern private sector employees. Table 2 shows a more detailed breakdown of total "occupational pensions and annuities" in 2007.

The bulk of income from "occupational pensions and annuities" - 17.5 points out of 18.7 - comes from occupational pension plans. Americans rarely choose to purchase annuities with their savings. It should be noted that, whereas only about 17 per cent of employees work in the public sector, public sector pension plans provide practically as much retirement income as private sector pension plans: 8.7 per cent of the total as compared to 8.8 per cent.

The category "income from assets" comprises interest and dividends, rental income from real estate, royalties and income from estates or trusts. In 2007, this category of income accounted for 15.6 per cent of the total income of the older population.

The distinction between "occupational pensions and annuities" and "income from assets" is not always clear-cut. When an occupational plan pays out a pension, the flow of income is usually included in the category "occupational pensions and annuities". However, occupational pension plans often pay out lump sums to employees when they leave the covered group before retirement and they sometimes offer a lump sum in lieu of a pension to employees upon retirement. Households who receive a lump sum tend to report the money as part of their assets. Hence, income from occupational plans may be underestimated.

The category "other income" comprises gifts from friends and family, and public assistance payments, notably from a federal programme for the aged poor and for poor younger people who are deemed unable to work. (This programme is called Supplemental Security Income or SSI.) State and local governments also provide means-tested benefits to the elderly. However, on the whole, older Americans depend little on public assistance. Since the expansion of Social Security following World War II, Americans have come to feel that old people should receive income primarily from social insurance rather than public assistance. In 2007, the category "other income" accounted for 1.8 per cent of the total income of the older population. (Within the category, public assistance accounted for only 0.1 per cent of total income.) 


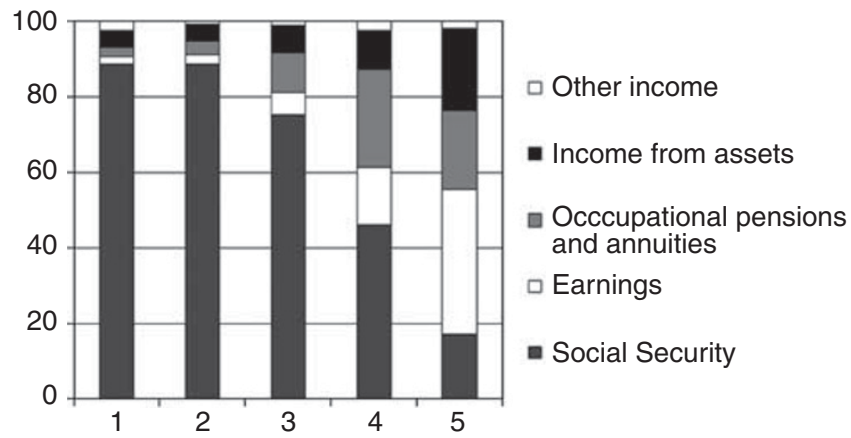

Figure 1. Income of population age 65 and over by source, by income quintile, 2007. Source: EBRI (2008, Table 7.5).

Data for the older population as a whole do not reflect differences between income groups. Figure 1 shows the composition of incomes of the older population by income quintile.

Social Security is a crucial component of retirement income for a large majority of older Americans. It provides the bulk of their incomes to households in the first three quintiles, that is, the 60 per cent of the older population with the lowest incomes: 89 per cent for the first two quintiles and 75 per cent for the middle quintile. The share of income from Social Security is much lower for the two quintiles with the highest incomes. In contrast, the shares of income from earnings, from occupational pensions and annuities, and from assets rise with the level of income.

In particular, occupational pensions are closely linked to income levels. They account for only about 3 per cent of the incomes of the two quintiles with the lowest incomes. The middle quintile derives 11 per cent of their incomes from that source, whereas the two quintiles with the highest incomes derive over a fifth of their incomes from occupational pensions. Employees with high wages receive occupational pensions more frequently than those with low wages and their occupational pensions are higher on average.

Unlike occupational pension plans, Social Security guarantees higher replacement rates to people with lower wages. Ever since the programme's creation in 1935, its benefit schedule has been skewed in favour of workers with low wages. The higher the workers' wages, the lower their replacement rate, that is, the lower the pension in relation to wages. Table 3 illustrates this effect for a hypothetical career: a worker who has been employed full time for at least 35 years since the age of 22 and who began to draw a Social Security pension as early as possible, that is at age 62, in 2005.

The pension is higher for people with higher wages, but their replacement rate is lower. The highest possible pension is awarded to people who have earned at least the Social Security ceiling, which is about 2.4 times the average wage. The maximum pension is equivalent to only about 1.5 times the pension for someone who has always earned the average wage. The system is not flat rate, since those with higher wages receive higher pensions. Nor is it proportional to earnings, since those with low wages receive a higher pension in relation to their wages. 
The Geneva Papers on Risk and Insurance - Issues and Practice

622

Table 3 Social security pensions according to wage level, 2005

\begin{tabular}{lcccc}
\hline & $\begin{array}{c}75 \% \text { of average } \\
\text { wage }\end{array}$ & $\begin{array}{c}\text { Average } \\
\text { wage }\end{array}$ & $\begin{array}{c}150 \% \text { of average } \\
\text { wage }\end{array}$ & $\begin{array}{c}\text { Social security } \\
\text { ceiling }\end{array}$ \\
\hline Last monthly wage & 2,309 & 3,079 & 4,619 & 7,500 \\
First monthly pension & 816 & 993 & 1,279 & 1,504 \\
Replacement rate & $35 \%$ & $32 \%$ & $28 \%$ & $20 \%$ \\
\hline
\end{tabular}

The hypothetical career is for a person retiring at age 62 in 2005 after working for at least 35 years since age 22 at the same relative wage level.

Wages and pensions in U.S. dollars.

Source: SSA, various years, and author's calculations.

\section{Recent changes in the retirement system}

The two main components of the retirement system have changed over recent years. Major amendments were enacted in legislation concerning Social Security in 1983, resulting initially in an increase in contributions and later in a decrease in benefits. Coverage by occupational pension plans has dwindled. At the same time, more and more companies have set up optional retirement savings plans for their employees.

\section{Changes in social security pensions}

Ever since its inception, Social Security has held reserves in the form of government treasury bonds. In periods when income from contributions exceeds expenditures, the surplus goes into the federal budget, which registers a debt vis-à-vis Social Security and pays interest to Social Security on the debt. In periods when expenditures exceed income from contributions, Social Security draws on its reserves, without having to seek authorization from the Congress. This financing mechanism gives Social Security a certain financial autonomy from the federal government budget.

In the early 1980s, Social Security's reserves were almost depleted and there was a risk that the programme would not be able to pay out all the benefits due. As a result, a major reform was enacted by Congress in 1983. An increase in Social Security contribution rates quickly went into effect. Since then, Social Security has been collecting more in contributions than it pays out in benefits. This has resulted in a build up of its reserves, which are currently equivalent to over three times annual expenditures and are expected to reach a maximum of almost four times annual expenditures around 2016. After that, Social Security will begin drawing down its reserves. Projections carried out in 2009 foresee that the reserves will be exhausted around 2037 if there are no further cutbacks in benefits or increases in contributions. ${ }^{2}$

The 1983 reform reduced pensions, but later and more slowly than the increase in contributions. The change consists of a decrease in pensions for people retiring before the age of 67 and an increase for those retiring between 68 and 70 . This will be achieved through two measures: first, a change in the pension schedule has widened

\footnotetext{
${ }^{2}$ OASDI Board of Trustees (2009).
} 
the gap between the pensions awarded for early and late retirement; second, the "Full Retirement Age" is due to rise from its previous level of 65 to 67 . However, the reform has not changed the age at which people may begin to draw a pension, which is still 62 .

The increases for people who delay getting a pension went into effect between 1990 and 2009. Hence, the initial impact of the reform was to raise pension levels for people who retire after the Full Retirement Age.

The Full Retirement Age began to move up in 2000. For people reaching age 62 in 2000 , it was 65 years and 2 months instead of 65. By 2005, it had reached 66 (for people turning age 62 in that year) and it is scheduled to remain at that age until 2016. Subsequently, it is due to increase again and reach 67 for people attaining age 62 in 2022. When the reform is fully in place, people retiring at age 62 will get 12.5 per cent less than before the reform, those retiring at 65 will get 10 per cent less, those retiring at 68 will get about the same amount as before the reform, and those retiring at 70 will get about 7 per cent more.

Another measure adopted by the 1983 reform was to make Social Security pensions subject to income tax. Previously, they were excluded from taxable income. Further legislation passed in 1993 increased the amount of Social Security pensions that are taxable. Proceeds from the tax on pensions go to Medicare, the social insurance programme that covers health expenditures for people age 65 or more. A Social Security pension is included in taxable income for a beneficiary whose total income exceeds an annual threshold (\$25,000 for an individual and $\$ 32,000$ for a married couple in 2009). In 2004, 40 per cent of beneficiaries had their pensions taxed and the total tax amounted to 4.4 per cent of all Social Security pensions. ${ }^{3}$ This measure has in effect reallocated social insurance expenditures, cutting retirement benefits and increasing the revenues of the social health insurance system.

The following data give a picture of long-term trends in the level of Social Security pensions. Figure 2 shows the ratio between the average Social Security retirement pension and the average wage of contributing employees from 1940 to 2007. This indicator compares the pensions of all retirees of all ages to the earnings of all contributing workers of all ages.

When the very first pensions were paid out in 1940, they were equal, on average, to 27 per cent of the average wage. Pensions were not re-evaluated until 1950, so the ratio declined over the 1940s. After 1950, pensions more or less kept pace with wages; the average pension ranged between 20 per cent and 28 per cent of the average wage. The ratio rose quite rapidly from 1971 to 1982 , when it surpassed 40 per cent. It began to decline in the early 1990s and was equal to 36 per cent in 2007. Much of the decline was due to the decision, taken in the 1970 s, to index pensions in payment to prices instead of wages. Since wages usually rise more quickly than prices, the longer the period over which retirees draw a pension, the lower their pensions become in relation to current wages. As life expectancy increases, if people do not postpone retirement, the gap between pensions and current wages will grow larger.

Future developments will depend a great deal on the age at which people begin to draw Social Security pensions. If Americans delay retirement sufficiently, they will be

\footnotetext{
${ }^{3}$ Committee on Ways and Means (2004).
} 


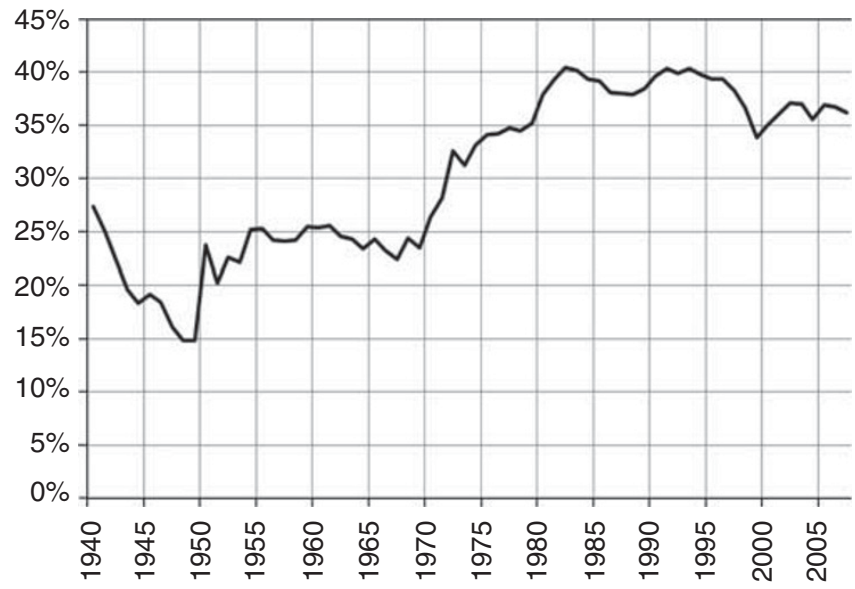

Figure 2. Average social security retirement pension as a percentage of average wage, 1940-2007. Source: SSA, various years, and author's calculations.

able to maintain their replacement rates. If they continue to retire at the same ages as currently, replacement rates will drop considerably.

\section{Changes in occupational pension and savings plans}

Since the 1970s, many companies have wound up their occupational pension plans and the number of active employees covered by such plans has dropped steadily. In 1980, about 39 per cent of private sector employees were affiliated to a pension plan; the proportion is now below 20 per cent. However, coverage by occupational pension plans in the public sector is virtually universal and has not declined.

In 1982, federal regulations authorized a new kind of employee retirement savings plans, commonly called $401(\mathrm{k})$ in reference to the number of the article concerning them in the tax code. Since then, many companies have set up such plans. Employees may make optional tax-free contributions; the employer usually makes additional contributions for employees who decide to contribute. Departing employees may withdraw their savings. Employees who deposit these savings in an Individual Retirement Account until the age of 59 and a half benefit from certain tax exemptions. However, employees are free to deposit the savings elsewhere or to spend the money. They may use the money accumulated in a retirement savings plan to purchase an annuity, but in fact they rarely do so. Thus employee retirement savings plans do not necessarily provide income in retirement.

Americans often use the term "pension plan" to refer, not only to occupational plans that pay out retirement pensions, but also to retirement savings plans that pay out lump sums when employees leave their employers. In order to distinguish between the two, they refer to plans that pay out pensions as "defined benefit plans", meaning that the pension is based on seniority and wage levels, independently of how the pension is financed, and "defined contribution plans", meaning that the employer 
contributes to the savings plan but makes no commitment as to the level of the benefit. Confusingly, the term "pension" is frequently used to refer to a lump sum paid out by a savings plan.

In this article, "pension plan" refers to plans that offer retirement pensions and "retirement savings plan" refers to plans that allow employees to accumulate savings. An employer who runs a pension plan may offer a lump sum in lieu of a pension to a departing employee, but the employer must offer a pension, unless the amount is very small. Pension plans are dedicated to retirement income, whereas income from employee retirement savings plans may be spent once employees leave their employer and they do not provide a stream of income in retirement.

Many factors have contributed to the decline of occupational pension plans. Federal regulations concerning private sector pension plans became considerably more stringent after 1974, in particular as regards requirements for building up reserves to finance future pensions. Another factor leading to the decline of pension plans is the decline in private sector unionization; unions favour occupational pension plans.

Above all, by closing a pension plan, an employer can reduce labour costs and avoid financial risk. Even if an employer replaces a pension plan with a retirement savings plan, the company saves on costs, since employer contributions to savings plans are generally much lower than those required to finance pension plans. A pension plan requires a company to build up assets in a pension fund over decades and to pay out benefits for many years. Companies are increasingly reluctant to bear the expense and risk of financing pensions. Regulations allow them to bow out of future pension promises on condition that they pay what is due to retirees and current employees to date.

\section{Employment among the older population}

Many older Americans earn income from employment. Certain federal policies adopted in the 1960s have facilitated older people's exit from the labour force. In 1961, the age at which beneficiaries may begin to draw a Social Security retirement pension was lowered from 65 to 62 . That decision was in part in reaction to a rise in unemployment. But the earliest retirement age has not changed since. The 1965 creation of Medicare, a social health insurance programme for people age 65 and over, probably facilitates exit from the labour force for the older population. Younger Americans generally depend on occupational health insurance provided by an employer.

However, unlike many countries in continental Europe, the United States did not generally encourage older workers to leave the labour force in the face of unemployment during the 70 s and 80 s. Unemployment benefits in the United States are low compared to those in Europe. Older people do not receive higher unemployment benefits than younger people, nor do they receive unemployment benefits for longer periods of time. The conditions required to qualify for Social Security disability pensions were not made less stringent for older people.

A policy change that may favour employment among older Americans is legislation forbidding discrimination against older employees. In 1967, the Age Discrimination in Employment Act forbade dismissal of employees under the age of 65 on grounds of 


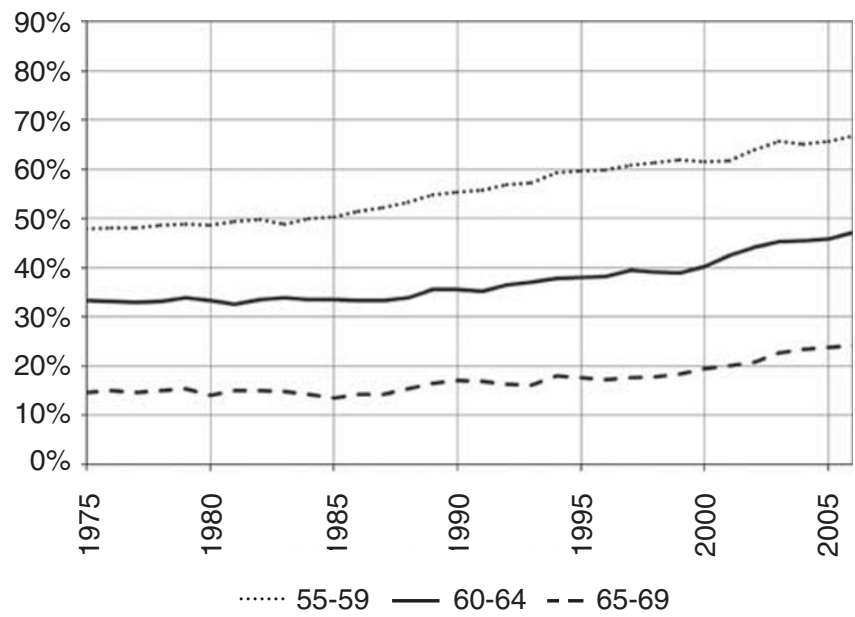

Figure 3. Labour force participation of older women by age, 1975-2007.

Source: Copeland (2007).

age; since 1987, employers may not lay off employees at any age on grounds of age. At the same time, the decline in unionization in the private sector has brought an end to protection against layoffs for workers with high seniority in many companies, so that older workers are often laid off in the same proportions as younger workers.

On the whole, labour force participation among people age 55-69 is quite high in the United States compared to continental Europe. The following data show the proportion of older Americans who were either working or actively seeking work from 1975 to 2007. People are divided into three age groups: 55-59, 60-64, and 65-69. Between 1975 and 2007, the overall participation of older people in the labour force increased; it rose from 65.1 per cent to 72.0 per cent for those of age 55-59, from 48.2 per cent to 52.5 per cent for those of age 60-64 and from 22.1 per cent to 29.0 per cent for those of age 65-69.

The overall increase in participation rates was mostly due to women, whose participation rate rose consistently at all ages over the whole period (Figure 3). Trends were less uniform for men (Figure 4). Until the mid-1990s, the participation rate of men in the 55-59 age group dropped steadily, from 84.4 per cent in 1975 to 76.9 per cent in 1994. After 1994, their participation rate fluctuated between 77.1 per cent and 78.4 per cent. The participation rate for men in the 60-64, and 65-69 age groups followed a similar pattern until 1994. However, since 1994, their participation rates have increased markedly.

A number of factors could explain the current rise in labour force participation of the older population. Women in all age groups, including younger women, have been joining the labour force in steadily increasing proportions for several decades.

Changes in Social Security rules may have contributed to the rise in labour force participation among the older population. Work at older ages, especially after the Full Retirement Age, now increases a Social Security pension by more than before the 1983 


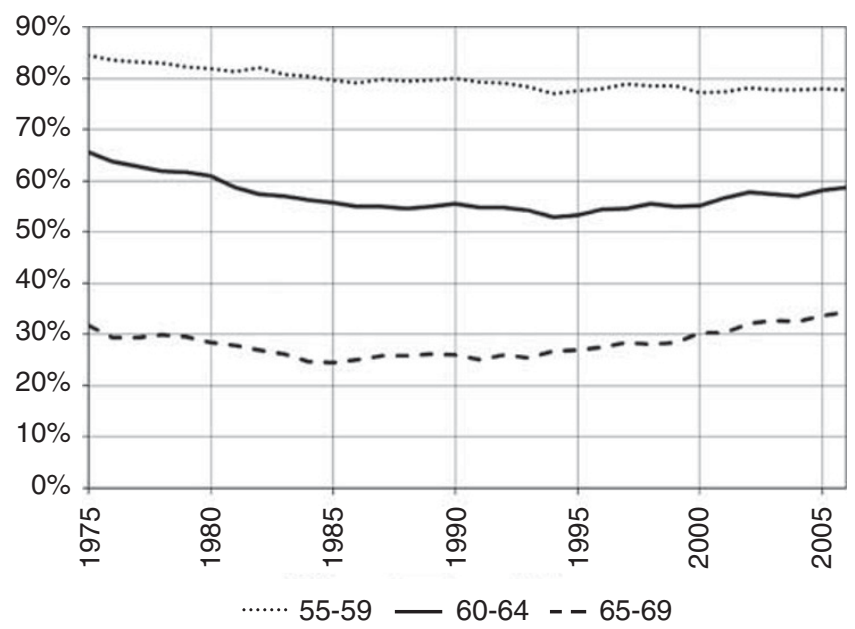

Figure 4. Labour force participation of older men by age, 1975-2007.

Source: Copeland (2007).

reform. Social Security discourages earnings among beneficiaries who are below the Full Retirement Age. For those who are between 62 and the Full Retirement Age (currently 66), a proportion of their earnings are deducted from their pensions. Beneficiaries below the Full Retirement Age may earn up to a threshold with no reduction in their pensions; if they earn more, 50 per cent of their earnings above the threshold are deducted from their pensions. (In 2008, the threshold was $\$ 13,540$ per year.) Legislation in 2000 abolished reductions for beneficiaries who have reached the Full Retirement Age, however much they earn. Thus, Social Security rules tend to encourage work after age 66.

Other factors may also have contributed to the rise in participation rates. One could be the decline in occupational pension plans and changes in their benefit rules. In the past, such plans featured incentives for workers to retire at certain ages; incentives for early retirement have been phased out in many of the occupational pension plans that have been maintained. Generally, health has improved at older ages over time, making it possible for more older people to work. In addition, it may be that many jobs have become less physically demanding than in the past. Another factor that might facilitate employment among older people is the fact that they have higher levels of education than previous generations, which means that they can more easily compete with younger workers. Recently, many older workers who were counting on retirement income from savings or real estate have been confronted with large drops in the value of their assets because of the financial crisis.

Another factor is the decline in occupational health insurance for retirees. Medicare provides health insurance to older people beginning only at age 65 . Until recently, many employers paid for continuing health insurance for departing older workers until they reached age 65. Now, few employers offer this benefit, so employees lose health coverage if they stop working before 65. Individual premiums for health insurance at older ages are prohibitively expensive. Older people often remain insured either by 
getting occupational insurance through new employment or through a working spouse. Maintaining health insurance coverage is a powerful incentive for older Americans to continue working at least until age 65 .

\section{The outlook for the retirement system}

If current trends in the retirement system continue, more Americans might face a shortfall in their incomes at older ages. The Center for Retirement Research at Boston College has developed projections of the proportion of working age Americans expected to have an inadequate income in retirement. ${ }^{4}$ Their definition of inadequate is income below 90 per cent of a target replacement rate which depends on income level and on whether people are living alone or in a couple. Based on the assumption that people retire at age 65 , which is later than the current average retirement age, and the assumption that they convert all of their assets into annuities at retirement, they project that 43 per cent of all households of current workers will have inadequate incomes in retirement. The proportion is higher for the younger the age group: 35 per cent of households of people born between 1946 and 1972 are expected to have inadequate retirement incomes; the proportion is 44 per cent for generations born between 1955 and 1964 and 49 per cent for generations born between 1965 and 1972.

The projected rise in the proportion of households with inadequate retirement incomes can be explained by several factors. The main factor is the drop in Social Security replacement rates resulting from the rise in the Full Retirement Age, even for people retiring at 65 . Furthermore, the proportion of couples whose two members have earned pension rights is rising and will undoubtedly continue to rise; a second earner's pension rights often add little or nothing to a couple's total Social Security pension. Increasing life expectancy also plays a role: on average, the number of years spent in retirement will rise, leading to lower annual retirement income from savings. Financial markets also have an influence, notably through the lower returns on assets, which decreases the annuitized value of assets.

Americans could maintain their retirement incomes if they worked at older ages or if they saved more. According to the Center for Retirement Research projections, if people retired at 67 instead of 65,32 per cent of households would have inadequate retirement incomes, instead of 43 per cent. (Conversely, if people retired at 62 instead of 65 , the proportion of households with inadequate retirement income would be 53 per cent instead of 43 per cent.) If households were to increase their savings rate by 3 per cent, the proportion with inadequate retirement incomes would be 36 per cent instead of 43 per cent.

In policy debates, concern is sometimes expressed about the drop in Social Security replacement rates. As the 1983 reform gradually comes into effect, successive cohorts who begin to draw a pension before the Full Retirement Age will get a lower and lower replacement rate. Since 2000, when the Full Retirement Age began to move up, there have been proposals to raise the early retirement age in line with the Full Retirement

\footnotetext{
${ }^{4}$ Munnell et al. (2006).
} 


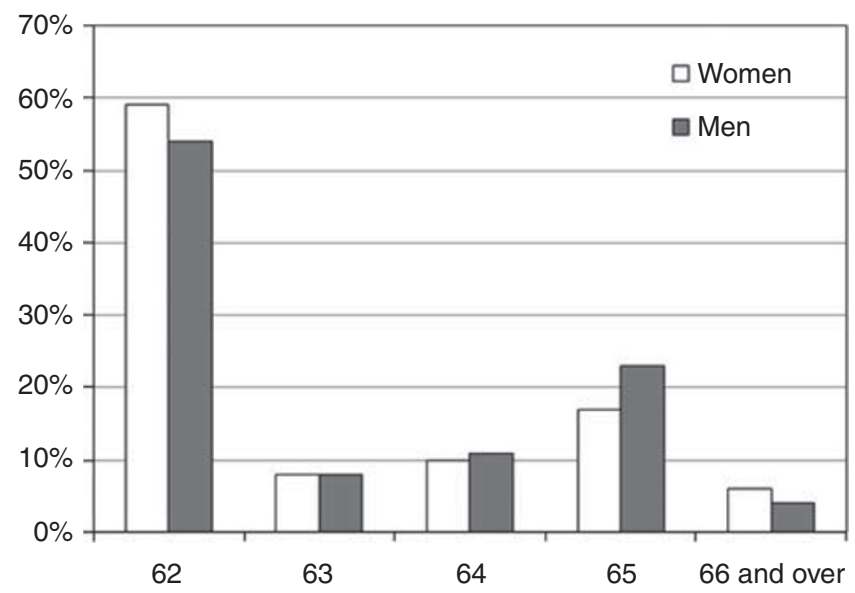

Figure 5. Distribution of beneficiaries of Social Security pensions, by the age at which the pension was first awarded, 2004.

Source: Munnell and Sass (2006).

Age, that is, by 2 years, from 62 to 64, between 2000 and 2022. If the early retirement age were raised, early retirees would attain about the same replacement rates as previous generations.

The main argument against such a change is that it would be hard on certain groups of older people: those with relatively short life expectancies, those who experience physical difficulties in working, and those who are unable to find employment. People who are getting an occupational pension between 62 and 64 would have a source of income. Others might have little or no income, unless they qualify for a Social Security disability pension or public assistance.

The earliest age of access to a Social Security pension seems to exert a strong influence on retirement behaviour. After 1961, when retirement was first authorized at 62 instead of 65, contributing workers rapidly began to draw pensions before age 65 . Figure 5 shows the distribution of all current Social Security retirement pension beneficiaries in 2004 by the age at which they first began to draw their pensions. A majority of beneficiaries - 59 per cent of the women and 54 per cent of the men began to receive a retirement pension at age 62 . However, a substantial proportion 17 per cent of the women and 23 per cent of the men - waited until age 65 to get a pension.

Recent trends in the labour market suggest that Americans might work more at older ages in future.

Increased savings could also give Americans more retirement income. However, savings rates are traditionally low in the United States. People often spend their savings before retirement and they rarely buy annuities. Requiring people to hold on to their assets until retirement or requiring them to convert assets into annuities would necessitate a set of complex regulations that might well discourage saving for retirement, unless it were made compulsory.

During his presidential campaigns, in 2000 and in 2004, George W. Bush proposed a certain form of compulsory retirement savings. He advocated diverting a portion of 
630

Social Security contributions into individual retirement savings accounts invested on financial markets, from which account holders would not be able to withdraw savings until retirement age. The proposal was withdrawn in 2005 in the face of opposition from Congress and public hostility.

The many Americans who have retirement savings plans have seen that assets do not provide a secure stream of retirement income. Except for those employed in the public sector, most working Americans no longer count on occupational pensions. In the face of cutbacks in Social Security pensions, some people will be able to boost their retirement incomes by postponing retirement or working after they start to get a pension.

Americans have seen that Social Security is more reliable than occupational pension plans or savings. However, the current political consensus is that pension levels should be reduced, contribution rates should not rise, and the minimum qualifying age of 62 for Social Security pensions should not be raised. If those policies remain in place in coming years, poverty will certainly become more common than today among older Americans.

\section{References}

Committee on Ways and Means (2004) Overview of Entitlement Programs, 2004 Green Book, Washington, D.C.: U.S. Government Printing Office.

Copeland, C. (2007) 'Labor force participation: The population age 55 and older', Employee Benefit Research Institute Notes 28(6) pp. 2-8.

EBRI (Employee Benefit Research Institute) (2008) 'Sources of income for persons aged 55 and over', EBRI Databook on Employee Benefits, Chapter 7, Washington, D.C.: EBRI, October.

Munnell, A.H. and Sass, S.A. (2007) The labor supply of older Americans, working paper no. 6 (June), Center for Retirement Research, Boston College, Boston, MA.

Munnell, A.H., Webb, A. and Delorme, L. (2006) 'A new national retirement risk index', An Issue in Brief Center for Retirement Research at Boston College, 48 (June).

OASDI Board of Trustees (2009) The 2009 annual report of the Board of Trustees of the Federal Old-Age and Survivors Insurance and Federal Disability Insurance Trust Funds, U.S. Government Printing Office, Washington, D.C.

SSA (Social Security Administration) (2009) Annual Statistical Supplement to the Social Security Bulletin, 2008 (Data were also drawn from previous editions of this annual publication).

Toder, E.J. (2005) 'What will happen to poverty rates among older Americans in the future and why?' Older Americans' Economic Security 3(November) pp. 1-2.

\section{About the Author}

Lucy apRoberts is an associate researcher at the social science laboratory "Institutions and Historical Dynamics of Economics" (IDHE) at the University of Paris Ouest Nanterre. She holds a doctorate in Economics and has written a book published in French on the American retirement system. Her research focuses on the interplay between social security and employer sponsored benefits. 